\title{
UNIVERSITÉ DU QUÉBEC A MONTRÉAL GEOTOP RADIOCARBON DATES I
}

\author{
J M M DUBOIS*, SERGE OCCHIETTI**, PIERRE PICHET**, \\ PIERRE PAGE**, CLAUDE JACOB** and PATRICE BIGRAS*
}

\section{INTRODUCTION}

GEOTOP is the geochemistry and geochronology research center of the Université du Québec à Montréal (UQAM). The Radiocarbon Laboratory was established to meet the growing demand for radiocarbon dating in Québec. The laboratory was founded by Claude Hillaire-Marcel. The first measurements were completed in October 1978. The laboratory was managed by Pierre Pagé until May 1985. Serge Occhietti and Pierre Pichet are presently in charge. Technical maintenance is under the direction of Claude Jacob.

The laboratory is equipped with two liquid scintillation counters (Intertechnique) which are installed in sub-basement three of a seven-story building.

Carbonate samples (eg, shells) are cleaned by dissolving 10 to $20 \%$ weight with $\mathrm{HCl}$. The $\mathrm{CO}_{2}$ is released using phosphoric acid at room temperature. Collagen is extracted from bones, according to the method described by Longin (1971), and conversion to $\mathrm{CO}_{2}$ is made by combustion bomb method (Switsur, 1974). Modern standard $\mathrm{CO}_{2}$ is prepared by oxidation of NBS oxalic acid (SRM 4990C) with $\mathrm{KMnO}_{4}$ in $2 \mathrm{~N} \mathrm{H}_{2} \mathrm{SO}_{4}$. $\delta^{13} \mathrm{C}$ measurements are carried out at GEOTOP on $\mathrm{CO}_{2}$ samples with a precision of $\pm 0.2 \%$.

Carbon dioxide is purified by passing through acetone/dry-ice water traps and then reacted with lithium at $700^{\circ} \mathrm{C}$. The $\mathrm{Li}_{2} \mathrm{C}_{2} / \mathrm{Li}$ mixture is cooled and $\mathrm{C}_{2} \mathrm{H}_{2}$ is obtained by adding water. The benzene is produced by trimerization of $\mathrm{C}_{2} \mathrm{H}_{2}$ on a $\mathrm{Cr}^{+3}$ catalyst at $60^{\circ} \mathrm{C}$ and trapped with liquid nitrogen and acetone/dry-ice. The benzene samples are stored for at least three weeks to ensure complete ${ }^{222} \mathrm{Rd}$ decay. They are stored and counted in numbered bottles with lead caps and bottoms. It has been observed that the background values were reduced by half when using those bottles.

Each sample is counted at least 12 times for 100 minutes, at $6^{\circ} \mathrm{C}$, alternating with 3 or 4 samples and commercial dead benzene used for background. The background values and the counting efficiencies are typically $4 \mathrm{cpm} / 58 \%$ and $2 \mathrm{cpm} / 53 \%$ for counters $\mathrm{A}$ and $\mathrm{B}$, respectively. From these values a merit figure of 1400 and 900 is obtained. The modern standard $\mathrm{CO}_{2}$ is regularly checked with a 100 -year-old wood sample. Age calculations are based on the $5570 \pm 30 \mathrm{yr}$ Libby ${ }^{14} \mathrm{C}$ half-life and on a contemporary value equal to 0.95 of the activity of the NBS oxalic acid standard. No corrections are made for ${ }^{14} \mathrm{C}$ fractionation and/or reservoir effect. Deviations

\footnotetext{
* Université de Sherbrooke, Département de géographie, Sherbrooke, Québec, Canada $\mathrm{J} 1 \mathrm{~K} 2 \mathrm{R} 1$

** Université du Québec à Montréal, GEOTOP, PO Box 8888, Montréal, Québec, Canada H3C 3P8
} 
reported as $\pm 1 \sigma$ include standard deviation of count rates on the background, the sample and modern standard. When the sample activity is below $2 \sigma$, the age is expressed as greater than the minimum calculated age.

\section{ACKNOWLEDGMENTS}

We express our gratitude to Claude Hillaire-Marcel, Director of GEOTOP, for his initial and continuous financial and scientific support to the laboratory. The Natural Sciences and Engineering Research Council of Canada provided the grants for the equipment. The Universite du Québec à Montréal gives financial support for salary and maintenance. The Department of Education of Québec (FCAR Foundation for Research Services) has continuously contributed to the operating costs. Many thanks to Michel Parent and to Bonnie Blackwell for reviewing the manuscript.

INTER-LABORATORY CHECK SAMPLES

\begin{tabular}{|c|c|c|c|c|}
\hline Sample & $\begin{array}{l}\text { GEOTOP } \\
\text { date }\end{array}$ & $\begin{array}{l}\text { Other } \\
\text { lab } \\
\text { no. }\end{array}$ & $\begin{array}{c}\text { Other } \\
\text { lab } \\
\text { date }\end{array}$ & Ref \\
\hline \multirow{4}{*}{$\begin{array}{r}\text { UQ-535 (wood) } \\
-555 \text { (wood) }\end{array}$} & $36,000 \pm 2000$ & GSC-3563 & $>42,000$ & Blake, pers commun \\
\hline & $25,200 \pm 450$ & GSC-1 802-2 & $25,200 \pm 260$ & Lowdon \& \\
\hline & & WAT-199 & $25,320 \pm 400$ & Blake (1979) \\
\hline & & BGS-303 & $25,620 \pm 300$ & \\
\hline-133 (shell) & $7395 \pm 80$ & SI-4089 & $7500 \pm 280$ & England (1978) \\
\hline -134 (shell) & $6790 \pm 410$ & SI-4029 & $6845 \pm 70$ & England (1983) \\
\hline
\end{tabular}

\section{GEOLOGIC SAMPLES}

\section{Anticosti Island series}

The Anticosti Island series (Gulf of St Lawrence), consists of 29 samples collected between 1981 and 1985 by members of a Univ de Sherbrooke research group. The main objectives of sampling program were to establish a sea-level curve for the island (Painchaud, 1984; Painchaud, Dubois \& Gwyn, 1984) and chronologic framework for Late Quaternary glacial and non-glacial events (Gratton, Gwyn \& Dubois, 1984). Detailed data and interpretations are pub in Bigras and Dubois (1987).

\section{UQ-493. Rivière du Brick}

$$
\begin{array}{r}
12,400 \pm 140 \\
\delta^{13} C=+1.9^{0} \% 0
\end{array}
$$

Shell fragments and a few complete specimens in growth position (Mya truncata ovata, Hiatella arctica) subm 1982 by J M M Dubois and coll 1981 by D Gratton and QHJ Gwyn from 4m depth in prodeltaic sand and silt overlying marine silt and clay $\left(49^{\circ} 21^{\prime} 28^{\prime \prime} \mathrm{N}, 63^{\circ} 23^{\prime} 22^{\prime \prime} \mathrm{W}\right)$. Alt of sample $18 \mathrm{~m}$ asl; same unit as UQ-498, -499, -508 and same site as UQ-512. Comment: age of prodeltaic sediments of Goldthwait Sea. 
Shell fragments (Hiatella arctica) subm 1982 by J M M Dubois and coll 1981 by $\mathrm{D}$ Gratton and $\mathrm{Q} \mathrm{H} \mathrm{J} \mathrm{Gwyn} \mathrm{from} 8 \mathrm{~m}$ depth in glaciomarine cobbly silts containing striated pebbles $\left(49^{\circ} 24^{\prime} 00^{\prime \prime} \mathrm{N}, 63^{\circ} 34^{\prime} 48^{\prime \prime} \mathrm{W}\right)$. Alt of sample $4 \mathrm{~m}$ asl; same site and same unit as UQ-502, same unit as UQ-505 and same sample as UQ-551. Comment: age for proximal glacio-marine sediments of Goldthwait Sea. In spite of low benzene volume used for counting, this date is more reliable than UQ-551.

\section{UQ-498. Rivière Jupiter}

$11,700 \pm 270$

Shell fragments and a few complete specimens in growth position (Mya truncata ovata) subm 1982 by J M M Dubois and coll 1981 by D Gratton and Q H J Gwyn from $5 \mathrm{~m}$ depth in deltaic sand (49. 29' $\left.31^{\prime \prime} \mathrm{N}, 63^{\circ} 31^{\prime} 53^{\prime \prime} \mathrm{W}\right)$. Alt of sample 23m asl; same unit as UQ-493, -499, -508. Comment: age of deltaic sediments of Goldthwait Sea.

\section{UQ-499. Rivière Jupiter}

$12,000 \pm 190$

Shell fragments and a few complete specimens in growth position (Mya truncata ovata) subm 1982 by J M M Dubois and coll 1981 by D Gratton and $Q \mathrm{H} \mathrm{J}$ Gwyn from 2m depth in prodeltaic sand (49 29' $26^{\prime \prime} \mathrm{N}, 63^{\circ} 32^{\prime} 20^{\prime \prime}$ W). Alt of sample $18 \mathrm{~m}$ asl; same unit as UQ-493, $-498,-508$ (same site). Comment: age of prodeltaic sediments of Goldthwait Sea.

\section{UQ-502. Côte Verte}

$\mathbf{1 3 , 5 7 0} \pm 200$

Shell fragments (Balanus sp) subm 1982 by J M M Dubois and coll 1981 by $\mathrm{D}$ Gratton and Q H J Gwyn from 3m depth in glacio-marine cobbly silt containing striated pebbles $\left(49^{\circ} 24^{\prime} 00^{\prime \prime} \mathrm{N}, 63^{\circ} 34^{\prime} 48^{\prime \prime} \mathrm{W}\right)$. Alt of sample $9 \mathrm{~m}$ asl; same unit and same site as UQ-496, -551 , and same unit as UQ-505. Comment: age of proximal glaciomarine phase of Goldthwait Sea.

UQ-505. Côte Verte

$13,200 \pm 200$

Shell fragments and a few complete valves (Hiatella arctica) subm 1982 by J M M Dubois and coll 1981 by D Gratton and Q H J Gwyn from 3m depth in glaciomarine sandy and cobbly silt with striated pebbles $\left(49^{\circ} 24^{\prime}\right.$ $47^{\prime \prime} \mathrm{N}, 63^{\circ} 34^{\prime} 42^{\prime \prime} \mathrm{W}$ ). Alt of sample $15 \mathrm{~m}$ asl; same unit as UQ-496, -502, -551. Comment: age of a proximal glaciomarine phase of Goldthwait Sea.

\section{UQ-508. Rivière Jupiter}

$$
12,080 \pm 280
$$

Rivière Jupiter anus crenatus, Hiatella arctica) subm 1982 by J M M Dubois and coll 1981 by D Gratton and Q H J Gwyn from 3m depth in prodeltaic sand and silt $\left(49^{\circ}\right.$ $29^{\prime} 26^{\prime \prime} \mathrm{N}, 63^{\circ} 32^{\prime} 20^{\prime \prime} \mathrm{W}$ ). Alt of sample $17 \mathrm{~m}$ asl; same unit as UQ-493, -498 and same site as UQ-499. Comment: age of prodeltaic sediments of Goldthwait Sea. 
UQ-509. Côte Verte

Shell fragments (Buccinum, Balanus spp) subm by 1982 J M M Dubois and coll 1981 by D Gratton and Q H J Gwyn from $11 \mathrm{~m}$ depth in glaciomarine cobbly sand containing striated pebbles $\left(49^{\circ} 24^{\prime} 36^{\prime \prime} \mathrm{N}, 63^{\circ} 34^{\prime} 40^{\prime \prime} \mathrm{W}\right)$. Alt of sample $7 \mathrm{~m}$ asl; same unit as UQ-553. Comment: this age for proximal glaciomarine phase agrees with UQ-510, -514 (obtained from shell material included in till).

\section{UQ-510. Pointe du Sud-Ouest}

$29,060 \pm 1050$

Unid shell fragments subm 1982 by J M M Dubois and coll 1981 by D Gratton and Q H J Gwyn from $1 \mathrm{~m}$ depth in silty clay till, $2 \mathrm{~m}$ thick, containing Precambrian clasts and overlying bedrock $\left(49^{\circ} 24^{\prime} 08^{\prime \prime} \mathrm{N}, 63^{\circ} 30^{\prime} 50^{\prime \prime}\right.$ W). Alt of sample $116 \mathrm{~m}$ asl; same unit as UQ-514. Comment: max age for glacial advance assoc with Anticosti Island Till; this date agrees with UQ514. Shells are probably derived from glacio-marine sediments in the TroisMilles brook (NW of site) which are correlatives of glacio-marine sediments at Côte Verte (UQ-509).

\section{UQ-512. Rivière du Brick}

$13,100 \pm 150$

$\delta^{13} C=+1.5 \%$

Shell fragments and a few complete specimens in growth position (Mya truncata) subm 1982 by J M M Dubois and coll 1981 by D Gratton and Q H J Gwyn from $8 \mathrm{~m}$ depth in marine silt and clay overlain by prodeltaic sediments $\left(49^{\circ} 21^{\prime} 28^{\prime \prime} \mathrm{N}, 63^{\circ} 23^{\prime} 22^{\prime \prime} \mathrm{W}\right)$. Alt of sample $14 \mathrm{~m}$ asl; same unit as UQ-712 and same site as UQ-493. Comment: age of deepwater phase of Goldthwait Sea.

\section{UQ-514. Pointe du Sud-Ouest}

$30,000 \pm 1200$

Shells (Hiatella arctica) subm 1982 by J M M Dubois and coll 1981 by D Gratton and $Q \mathrm{H} \mathrm{J}$ Gwyn from $2 \mathrm{~m}$ depth in silty clay till containing Precambrian clasts $\left(49^{\circ} 23^{\prime} 47^{\prime \prime} \mathrm{N}, 63^{\circ} 31^{\prime} 14^{\prime \prime} \mathrm{W}\right)$. Alt of sample $84 \mathrm{~m}$ asl; same unit as UQ-510. Comment: same interpretation as UQ-510.

\section{UQ-515. Côte Verte}

$11,950 \pm 150$

Shell fragments and a few unbroken valves (Mya truncata, Mya arenaria, Buccinum terrae-novae, Hiatella arctica) subm 1982 by J M M Dubois and coll 1981 by $\mathrm{D}$ Gratton and Q $\mathrm{H} \mathrm{J}$ Gwyn from $9 \mathrm{~m}$ depth in glaciomarine silty and cobbly sand $\left(49^{\circ} 24^{\prime} 16^{\prime \prime} \mathrm{N}, 63^{\circ} 34^{\prime} 38^{\prime \prime} \mathrm{W}\right)$. Alt of sample $3 \mathrm{~m}$ asl; same unit as UQ-738. Comment: age of proximal glaciomarine phase assoc with readvance of Anticosti I. residual ice cap.

\section{UQ-551. Côte Verte}

$\mathbf{1 4 , 5 0 0} \pm \mathbf{8 0 0}$

$\delta^{13} C=+7.4 \%$

Shell fragments (Hiatella arctica) subm 1982 by J M M Dubois and coll 1982 by $\mathrm{D}$ Gratton and Q H J Gwyn from $8 \mathrm{~m}$ depth in glaciomarine cobbly silt containing striated pebbles $\left(49^{\circ} 24^{\prime} 00^{\prime \prime} \mathrm{N}, 63^{\circ} 34^{\prime} 38^{\prime \prime} \mathrm{W}\right)$. Alt of sample $4 \mathrm{~m}$ asl; same site as UQ-502, same unit as UQ-505 and same sample as UQ- 
496. Same interpretation as UQ-496. Comment: this date may be less reliable than UQ-496 because of less benzene recovery.

\section{UQ-553. Baie Bonsecours}

$$
\begin{array}{rl} 
& \mathbf{3 6 , 0 0 0} \\
\delta^{13} C=+0.6 \% & 0
\end{array}
$$

Shell fragments (Balanus sp) subm 1982 by J M M Dubois and coll 1982 by $\mathrm{D}$ Gratton and Q H J Gwyn from $5 \mathrm{~m}$ depth in glaciomarine silty and cobbly sand containing striated pebbles $\left(49^{\circ} 28^{\prime} 45^{\prime \prime} \mathrm{N}, 63^{\circ} 36^{\prime} 50^{\prime \prime} \mathrm{W}\right)$. Alt of sample 1-2m asl; same unit as UQ-509. Comment: oldest date on Anticosti I., age of proximal glaciomarine phase. Sample should be crosschecked on proportional counter because of less benzene recovery. Date was previously considered finite $(36,000 \pm 3500$ BP; Gratton, Gwyn \& Dubois, 1984), age seems consistent with available amino acid ratios (Bigras, Gwyn \& Dubois, 1988).

\section{UQ-712. Ruisseau Martin}

$$
\begin{array}{r}
13,400 \pm 140 \\
\delta^{13} C=+5.5 \% \text { o }
\end{array}
$$

Shell fragments and a few complete specimens in growth position (Hiatella arctica) subm 1983 by J M M Dubois and coll 1982 by D Gratton and Q H J Gwyn from 3m depth in cobbly glaciomarine silt overlying till and underlying littoral gravel $\left(49^{\circ} 10^{\prime} 34^{\prime \prime} \mathrm{N}, 62^{\circ} 46^{\prime} 58^{\prime \prime} \mathrm{W}\right)$. Alt of sample $9 \mathrm{~m}$ asl; same unit as UQ-512. Comment: same interpretation as UQ-512.

\section{UQ-719. Rivière à l'Huile}

$9010 \pm 60$

Shell fragments and a few unbroken valves (Zirphaea crispata) subm 1983 by J M M Dubois and coll 1981 by A Painchaud in cobbly matrixdominated resedimented diamicton overlain by $6 \mathrm{~m}$ of littoral sandy gravel $\left(49^{\circ} 50^{\prime} 12^{\prime \prime} \mathrm{N}, 63^{\circ} 33^{\prime} 30^{\prime \prime} \mathrm{W}\right)$. Alt of sample $12 \mathrm{~m}$ asl. Comment: located on distal side of Rivière à l'Huile Moraine, date is min for moraine.

\section{UQ-738. Ruisseau Box}

$12,190 \pm 170$

Shells (Mya truncata, Hiatella arctica) subm 1983 by J M M Dubois and coll 1982 by D Gratton and Q H J Gwyn from $2 \mathrm{~m}$ depth in glaciomarine sandy and cobbly silt $\left(49^{\circ} 06^{\prime} 21^{\prime \prime} \mathrm{N}, 62^{\circ} 24^{\prime} 00^{\prime \prime} \mathrm{W}\right)$. Alt of sample 2 to $3 \mathrm{~m}$ asl; same unit as UQ-515. Comment: same interpretation as UQ-515.

\section{UQ-776. Baie Martin}

$\mathbf{9 4 5 0} \pm 200$

Shell material (mainly Mya truncata) subm 1983 by J M M Dubois and coll 1981 by A Painchaud in glaciomarine sandy silt incorporated in till $\left(49^{\circ}\right.$ $\left.52^{\prime} 25^{\prime \prime} \mathrm{N}, 63^{\circ} 52^{\prime} 10^{\prime \prime} \mathrm{W}\right)$. Alt of sample $10 \mathrm{~m}$ asl. Comment: sample coll within Rivière à l'Huile Moraine. Date is considered suspect because of low sample weight and small benzene recovery.

UQ-778. Rivière Sainte-Marie

$$
10,150 \pm 100
$$

Shells in growth position (Mya truncata) subm 1983 by J M M Dubois and coll 1981 by A Painchaud at surface of till overlain by $1.5 \mathrm{~m}$ of littoral gravel $\left(49^{\circ} 40^{\prime} 10^{\prime \prime} \mathrm{N}, 63^{\circ} 54^{\prime} 48^{\prime \prime} \mathrm{W}\right)$. Alt of sample $5 \mathrm{~m}$ asl; same unit as 
UQ-1018 and QU-1262 (11,680 \pm 190$),-1263(12,400 \pm 230),-1264$ $(11,830 \pm 180),-1265 \quad(12,090 \pm 210),-1268 \quad(12,300 \pm 180),-1269$ $(12,470 \pm 170),-1270(11,940 \pm 190)$ and $-1271(12,200 \pm 190)$ (Bigras \& Dubois, 1987). Comment: age of regressive level of Goldthwait Sea at alt ca 35 to $50 \mathrm{~m}$ asl according to mean depth range of this species.

\section{UQ-1018. Rivière aux Becs-Scie}

$$
13,450 \pm 300
$$

Unbroken shell valves (Macoma calcarea) subm and coll 1984 by J M M Dubois in thin till derived from glaciomarine sediments and overlain by 1 to $2 \mathrm{~cm}$ of littoral sand and $1.5 \mathrm{~m}$ of terrestrial peat $\left(49^{\circ} 42^{\prime} 09^{\prime \prime} \mathrm{N}, 64^{\circ} 05^{\prime} 10^{\prime \prime}\right.$ W). Alt of sample $3.3 \mathrm{~m}$ asl; same unit as UQ-778 and QU-1262 to -1265 and -1268 to -1271 (Bigras \& Dubois, 1987). Comment: age of Goldthwait Sea proximal glaciomarine sediments deposited prior to fm of Sainte-Marie Moraine.

\section{UQ-1036. Baie du Petit Makasti}

$\mathbf{4 7 0} \pm \mathbf{8 0}$
$\delta^{13} C=+1.7 \%$

Shells in growth position (Mya arenaria) subm and coll 1984 by J M M Dubois from veneer of Goldthwait Sea marine clay on modern intertidal rock-platform $\left(49^{\circ} 55^{\prime} 30^{\prime \prime} \mathrm{N}, 64^{\circ} 22^{\prime} 15^{\prime \prime} \mathrm{W}\right)$. Alt of sample $0 \mathrm{~m}$ asl; sampled in immediate vicinity of site of sample UQ-1376. Comment: this shallowwater species probably burrowed into older marine clay (UQ-1376) during Late Holocene phase of littoral erosion. Age of regressive level of Goldthwait Sea at site alt. Small benzene recovery.

\section{UQ-1056. Rivière aux Saumons}

$10,200 \pm 200$

Shell fragments (Hiatella arctica, Macoma sp) subm 1984 by L St-Pierre and coll 1984 by Q H J Gwyn, P Bigras and L St-Pierre from 13m depth at base of prodeltaic silt and sand overlying marine or glaciomarine silt and clay $\left(49^{\circ} 24^{\prime} 55^{\prime \prime} \mathrm{N}, 62^{\circ} 15^{\prime} 05^{\prime \prime} \mathrm{W}\right)$. Alt of sample $6 \mathrm{~m}$ asl. Comment: dates $42 \mathrm{~m}$ asl surface of Rivière aux Saumons delta into receding Goldthwait Sea.

\section{UQ-1063. Port-Menier Airport}

$11,600 \pm 200$

Shell fragments (mainly Mytilus edulis) subm 1984 by L St-Pierre and coll 1984 by L St-Pierre and D Côté from $2 \mathrm{~m}$ depth in prodeltaic sand and gravel $\left(49^{\circ} 50^{\prime} 05^{\prime \prime} \mathrm{N}, 64^{\circ} 15^{\prime} 50^{\prime \prime} \mathrm{W}\right)$. Alt of sample $61 \mathrm{~m}$ asl; same unit as QU-1272 (12,450 \pm 190$),-1273(12,510 \pm 200)$ and GSC-89 $(12,940 \pm 150)$ (Bigras \& Dubois, 1987). Comment: date is youngest date for fm of Trois-Milles brook outwash plain; outwash body which formed during sea-level stand at site alt is contemporaneous with Sainte-Marie Moraine.

\section{UQ-1064. Pointe Carleton}

$9500 \pm 100$

Shell fragments (mainly Mytilus edulis and Mya sp) subm 1984 by L StPierre and coll 1984 by P Bigras, L St-Pierre and D Côté from $2 \mathrm{~m}$ depth in littoral sand and gravel at surface of raised rock platform $\left(49^{\circ} 43^{\prime} 57^{\prime \prime} \mathrm{N}\right.$, 
$62^{\circ} 58^{\prime} 47^{\prime \prime} \mathrm{W}$ ). Alt of sample 26 to $29 \mathrm{~m}$ asl. Comment: age of regressive level of Goldthwait Sea at site alt.

\section{UQ-1066. Rivière à la Patate}

$10,600 \pm 200$

$\delta^{13} \mathrm{C}=+2.8 \%$

Shell fragments and a few unbroken specimens (mainly Mya truncata, Mya arenaria, Hiatella arctica) subm 1984 by L St-Pierre and coll 1984 by J M M Dubois, P Bigras and L St-Pierre from depth $17 \mathrm{~m}$ in marine silty clay overlain by $10 \mathrm{~m}$ of deltaic sand and gravel $\left(49^{\circ} 42^{\prime} 20^{\prime \prime} \mathrm{N}, 62^{\circ} 56^{\prime} 00^{\prime \prime} \mathrm{W}\right)$. Alt of sample 13 to $17 \mathrm{~m}$ asl; same unit as QU-1375, -1376 (Bigras \& Dubois, 1987). Comment: min age of deglaciation in E part of Jacques-Cartier Passage. Complete starfish (Ophiuroida) specimen, probably Asterias vulgaris or Henricia sanguinolenta, was also found at this site.

\section{UQ-1068. Pointe Carleton}

$1300 \pm 100$

Shell fragments (mainly Buccinum undatum, Mytilus edulis) subm 1984 by L St-Pierre and coll 1984 by P Bigras, L St-Pierre and D Côté from 2 to $3 \mathrm{~m}$ depth in beach sand and gravel at surface of raised littoral rock platform $\left(49^{\circ} 43^{\prime} 58^{\prime \prime} \mathrm{N}, 62^{\circ} 59^{\prime} 01^{\prime \prime} \mathrm{W}\right)$. Alt of sample 3 to $6 \mathrm{~m}$ asl. Comment: dates regressive level of Goldthwait Sea at site alt.

UQ-1082. Port-Menier Airport

$9850 \pm 300$

Whale vertebra (restored and exposed in Mus Nat Sci, Ottawa) subm 1984 by J M M Dubois and coll 1984 by Q H J Gwyn in beach gravel overlying fluvio-deltaic sediments $\left(49^{\circ} 50^{\prime} 00^{\prime \prime} \mathrm{N}, 64^{\circ} 17^{\prime} 30^{\prime \prime} \mathrm{W}\right)$. Alt of sample $49 \mathrm{~m}$ asl. Comment: dates regressive level of Goldthwait Sea at site alt.

\section{UQ-1375. Baie du Petit Makasti}

$9900 \pm 100$

Shells (Hemithyris psittacea, Mya truncata, Macoma balthica) in growth position subm 1986 and coll 1985 by J M M Dubois at 6m depth in marine clay overlain by deltaic sand and gravel $\left(49^{\circ} 55^{\prime} 20^{\prime \prime} \mathrm{N}, 64^{\circ} 21^{\prime} 30^{\prime \prime} \mathrm{W}\right)$. Alt of sample $3 \mathrm{~m}$ asl; same unit as UQ-1066, -1376. Comment: same interpretation as UQ-1066, -1376. Site provides first recorded occurrence of Crassostrea virginica this far $\mathrm{N}$ of its modern distribution area, boundary of which now lies near $47^{\circ} \mathrm{N}$.

UQ-1376. Baie du Petit Makasti

$13,900 \pm 300$

Shells in growth position (Hiatella arctica, Mya truncata) subm 1986 and coll 1985 by J M M Dubois from $25 \mathrm{~cm}$ depth in marine clay in depression of modern littoral rock platform $\left(49^{\circ} 55^{\prime} 30^{\prime \prime} \mathrm{N}, 64^{\circ} 22^{\prime} 15^{\prime \prime} \mathrm{W}\right)$. Alt of sample $0 \mathrm{~m}$ asl; near UQ-1036 and same unit as UQ-1066, -1375. Comment: min age of deglaciation of $\mathrm{W}$ part of Jacques-Cartier Passage. Late Wisconsinan marine clays at surface of modern platform indicates platform was formed prior to Late Wisconsinan time, possibly during Sangamonian stage.

\section{Baie-Comeau series}

Baie-Comeau series (North Shore of St Lawrence estuary) consists of 15 samples coll 1985 and subm 1986 by J M M Dubois. Samples were dated 
to document relative sea-level changes in this part of Goldthwait Sea (Dubois, 1979; Bigras \& Dubois, 1987) and to date marine limit; thus to provide min age for deglaciation of area. Most samples were coll in two secs exposing thick coquina beds with minor sand and gravel. These deposits underlay well-defined offlap terraces in small bays of former Rivière aux Anglais estuary. Site 1 is Rivière des Anglais-A (49 $17^{\prime} 25^{\prime \prime} \mathrm{N}, 68^{\circ} 09^{\prime} 45^{\prime \prime}$ W); $60 \mathrm{~m}$ asl; samples UQ-1229, -1230, -1360 and QU-573 (9600 \pm 130$)$ (Bigras \& Dubois, 1987) were coll in coquina beds which has exposed thickness of $1.7 \mathrm{~m}$. Site 2 is Rivière des Anglais-B $\left(49^{\circ} 19^{\prime} 15^{\prime \prime} \mathrm{N}, 68^{\circ} 09^{\prime} 20^{\prime \prime} \mathrm{W}\right)$ $76 \mathrm{~m}$ asl; samples UQ-1231 to $-1235,-1361$ and QU-574 (9970 \pm 130$)$ (Bigras \& Dubois, 1987) were coll in coquina beds thickness of which exceed $8 \mathrm{~m}$. Detailed data and interpretations are pub in Bigras and Dubois (1987).

\section{UQ-1229. Rivière des Anglais-A}

$9350 \pm 100$

Well-preserved shells (Balanus crenatus) from depth $40 \mathrm{~cm}$ assoc with Hiatella arctica, Mytilus edulis, Hemithyris psittacea and foram, Elphidium incertum. Comment: age of regressive sea level at $60 \mathrm{~m}$ asl; date agrees with GSC-1565 (9280 \pm 140$)$, QU-73 (10,000 \pm 170$)$ and QU-573 $(9600 \pm 130)$.

\section{UQ-1230. Rivière des Anglais-A}

$8600 \pm 100$

Well-preserved shells (Balanus crenatus) from depth 0.4 to $1.7 \mathrm{~m}$; same faunal assemblage as UQ-1229. Comment: date slightly too young for regressive sea level at $60 \mathrm{~m}$ asl (5 dates).

\section{UQ-1360. Rivière des Anglais-A}

$11,600 \pm 300$

Comment: this date, intended as cross-check of UQ-1230, same species, should be used with caution since only $0.947 \mathrm{~g}$ benzene was used for counting. Date seems somewhat too old relative to other dates at same alt in area.

\section{UQ-1231. Rivière des Anglais-B}

$9850 \pm 100$

Well-preserved shells (Mytilus edulis) from depth 40 to $50 \mathrm{~cm}$ assoc with Balanus balanus, Balanus crenatus, Mya truncata, Natica clausa, Hiatella arctica, Buccinum tenue, a few Chlamys islandicus, Macoma balthica, Astarte montagui striata, Balanus hameri, Hemithyris psittacea and one valve of Zirphaea crispata. Comment: age for regressive sea level stand at $76 \mathrm{~m}$ asl. UQ-1231, $-1232,-1233$ show expected age increase with depth, but UQ-1234, -1235, -1361 , at greater depth, are more problematic.

\section{UQ-1232. Rivière des Anglais-B}

$$
10,000 \pm 100
$$

Well-preserved shells (Mytilus edulis) from depth 2.2 to $2.4 \mathrm{~m}$. Comment: age for regressive sea level at $76 \mathrm{~m}$ asl; age agrees with strat position. 
UQ-1233. Rivière des Anglais-B $\quad \delta^{13} C=0.4 \%$ age for regressive sea level at $76 \mathrm{~m}$ asl; agrees with strat position.

\section{UQ-1234. Rivière des Anglais-B}

$10,200 \pm 100$

$\delta^{13} \mathrm{C}=0.1 \%$

Well-preserved shells (Mytilus edulis) from depth $4 \mathrm{~m}$. Comment: age for regressive sea level at $76 \mathrm{~m}$ asl; if stated errors $( \pm 1 \sigma)$ are considered, this date may be identical to or slightly older than UQ-1233.

\section{UQ-1235. Rivière des Anglais-B}

$9600 \pm 200$

Well-preserved shells (Balanus crenatus) often fixed on other shells from depth $4 \mathrm{~m}$; same sample as UQ-1234. Comment: this date is significantly younger than UQ-1233 and -1234; date may be suspect, particularly since low benzene volume was used for counting.

\section{UQ-1361. Rivière des Anglais-B}

$12,600 \pm 200$

Comment: this date was intended as cross-check of UQ-1235, but on mixed species (see assemblage UQ-1231); same problem as UQ-1360. Apparent antiquity of this date may be caused by reworked shells from older sediments; however, only small amount of benzene was used for counting; date should be used with caution.

\section{UQ-1236. Baie-Comeau}

$9050 \pm 100$

$\delta^{13} C=+0.4 \%$

Shells (Mya arenaria) coll from depth 0 to $1 \mathrm{~m}$ in silty marine sediment $\left(49^{\circ} 13^{\prime} 00^{\prime \prime} \mathrm{N}, 68^{\circ} 11^{\prime} 40^{\prime \prime} \mathrm{W}\right)$. Alt of sample $60 \mathrm{~m}$ asl; same site as GSC1565 (Bigras \& Dubois, 1987) and same unit as UQ-1237; thanacoenotic assemblage also contains Balanus crenatus, Mytilus edulis, Hiatella arctica, Hemithyris psittacea and a few Astarte montagui, Macoma balthica, Venericardia borealis. Comment: age slightly too young for regressive level of Goldthwait Sea at site alt; date is consistent with UQ-1229, -1237, QU-573 and GSC1565 .

\section{UQ-1237. Baie-Comeau}

$$
10,000 \pm 100
$$

$\delta^{13} C=+2.3 \% 0$

Shells (Mya truncata) coll near surface in veneer of silty marine sediment on bedrock $\left(49^{\circ} 13^{\prime} 00^{\prime \prime} \mathrm{N}, 68^{\circ} 11^{\prime} 40^{\prime \prime} \mathrm{W}\right)$. Alt of sample $56 \mathrm{~m}$ asl; same unit as UQ-1236 and GSC-1565 (Bigras \& Dubois, 1987); thanacoenotic assemblage also contains Chlamys islandicus, Macoma calcarea, Balanus hameri and a few Cyrtodaria siliqua, Astarte montagui, Hemithyris psittacea, Venericardia borealis, Buccinum hancocki. Comment: date is too old for regressive level of Goldthwait Sea at site alt, presumably because shells were reworked from sediments deposited earlier during marine invasion; min age for marine invasion in area. 


\section{Q-1238. Baie-Comeau (Pointe Saint-Gilles) \\ Baie-Comeau (Pointe Saint-Gilles)}

Shells (Balanus crenatus) coll near surface in marine silty and clayey sand containing pebbles and cobbles $\left(49^{\circ} 11^{\prime} 55^{\prime \prime} \mathrm{N}, 68^{\circ} 10^{\prime} 25^{\prime \prime} \mathrm{W}\right)$. Alt of sample $30 \mathrm{~m}$ asl; same unit as UQ-1 239 and GSC-1 $746(8890 \pm 150)$; thanacoenotic assemblage also contains Chlamys islandicus, Hemithyris psittacea and a few Astarte montagui, Macoma balthica, Mya truncata, Hiatella arctica, Buccinum hancocki, Natica clausa. Comment: same interpretation as UQ1237.

\section{UQ-1239. Chute-aux-Outardes}

$\mathbf{7 8 0 0} \pm \mathbf{5 0 0}$

Thin, dwarf shells in growth position (Macoma balthica) coll at the base of $4.9 \mathrm{~m}$ of compact marine sediment overlain by $4 \mathrm{~m}$ of deltaic sand and gravel $\left(49^{\circ} 07^{\prime} 40^{\prime \prime} \mathrm{N}, 68^{\circ} 22^{\prime} 20^{\prime \prime} \mathrm{W}\right)$. Alt of sample $21 \mathrm{~m}$ asl; same unit as UQ-1238 and GSC-1746. Comment: age is mainly indicative because only $0.3 \mathrm{~g}$ of benzene were recovered from this $5 \mathrm{~g}$ sample; age for marine sediments underlying part of delta of Rivière aux Outardes ca $30 \mathrm{~m}$ asl.

UQ-1362. Baie-Comeau

$9900 \pm 200$

Shells (Balanus crenatus) coll from depth $60 \mathrm{~cm}$ in beach sand and fine

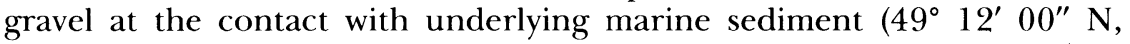
$\left.68^{\circ} 11^{\prime} 15^{\prime \prime} \mathrm{W}\right)$. Alt of sample $23 \mathrm{~m}$ asl; probably same site GSC-1746 $(8890 \pm 150)$; assemblage also contains Clinocardium ciliatum, Astarte montagui, Macoma balthica, Macoma calcarea. Comment: age too old for regressive level of Goldthwait Sea at site alt. This date should be used with caution because of small benzene recovery.

\section{UQ-1363. Pointe-aux-Outardes}

$7600 \pm 150$

Shells in growth position (Mya arenaria) coll from depth $0.4 \mathrm{~m}$ in compact marine sediment overlain by $3.7 \mathrm{~m}$ of beach sand and $0.9 \mathrm{~m}$ of aeolian sand $\left(49^{\circ} 02^{\prime} 30^{\prime \prime} \mathrm{N}, 68^{\circ} 27^{\prime} 45^{\prime \prime} \mathrm{W}\right)$. Alt of sample $2 \mathrm{~m}$ asl. Comment: same interpretation as UQ-1239. This date should be used with caution because of small benzene recovery.

\section{REFERENCES}

Bigras, $\mathrm{P}$ and Dubois, J M M, 1987, Répertoire commenté des datations ${ }^{14} \mathrm{C}$ du nord de l'estuaire et du golfe du Saint-Laurent, Québec et Labrador: Dépt géog, Univ Sherbrooke, Bull rech no. 94-96, $166 \mathrm{p}$.

Bigras, P, Gwyn, Q H J and Dubois, J M M, 1988, Aminostratigraphie des sédiments de l'île d'Anticosti, Québec: analyse préliminaire: Dépt géog, Univ Sherbrooke, Bull rech no. 97, $70 \mathrm{p}$.

Dubois, J M M, (ms)1979, Environnements quaternaires et évolution postglaciaire d'une zone côtière en émersion en bordure sud du Bouclier Canadien: la Moyenne Côte Nord du Saint-Laurent: Ph D dissert, Univ Ottawa, 754 p.

England, J, 1978, The glacial geology of northeastern Ellesmere Island, NWT, Canada: Can Jour Earth Sci, v 15, p 603-617. 917.

Gratton, D, Gwyn, Q H J and Dubois, J M M, 1984, Les paléoenvironnements sédimentaires au Wisconsinien moyen et supérieur, île d'Anticosti, golfe du Saint-Laurent, Québec: Géog Phys Quaternaire, v 38, p 229-242. 

Longin, R, 1971, New method of collagen extraction for radiocarbon dating: Nature, v 1230 ,
p 24l-242.

Lowdon, J A and Blake, W, Jr, 1979, Geological Survey of Canada radiocarbon dates XIX: Geol Survey Canada, Paper 79-7, p 21.

Painchaud, A, (ms) 1984, Le quaternaire du tiers ouest de l'île d'Anticosti; mise en relief des aspects de la déglaciation: M Sc thesis, Univ Sherbrooke, 322 p.

Painchaud, A, Dubois, J M M and Gwyn, Q H J, 1984, Déglaciation et émersion des terres de l'ouest de l'île d'Anticosti, golfe du Saint-Laurent, Québec: Géog Phys Quaternaire, v 38, p 93-111

Switsur, V R, 1974, A new sample combustion bomb for radiocarbon dating: Appl Radiation \& Isotopes, v 25, p 113-117. 